\title{
EFFECT ON PLANT LIFE OF INDUSTRIAL DEVELOPMENT IN THE NORTH-EAST OF ENGLAND
}

\section{A} CONFERENCE on North-East Development and the Plant Sciences, organized by the Department of Botany, University of Durham, was held at the Science Laboratories, Durham, on March 14. The chair at the morning session was taken by Mr. T. Pritchard of the Nature Conservancy, and at the afternoon session by Mr. Charles Grey, Member of Parliament for Durham.

The conference was opened by the Mayor of Durham, Councillor N. Richardson, who welcomed the opportunity afforded by the conference for discussion between the University and the many organizations in town and country who were concerned with the development of the North-East. He referred to his own interest in the importance of the tourist industry and to the part that science could play in the development of regional resources and amenities.

Prof. D. H. Valentine spoke next about Nature conservation. He began by explaining the case for conservation, which rested first on amenity and the protection of Nature, secondly, on scientific grounds and, thirdly, on educational value. A recent survey (Science out of Doors, Longmans, 1963) had shown that the amount of time devoted to field studies in schools by pupils between the ages of 11 and 16 averaged no more than $2 \mathrm{~h}$ a week. Training in the field studies, and in the scientific disciplines of ecology and evolution, had great value in contributing towards an understanding of human societies, and also in providing a means of using leisure time constructively. On the basis of the ecological concepts of climax and succession, Prof. Valentino outlined a broad plan of conservation for the North-East. This would involve the establishment of a series of nature reserves and protected areas, designed to cover a wide variety of habitat types. These would be selected and managed by a planning authority, working in co-operation with the Nature Conservancy, the Natural. ists' Trust and other voluntary bodies. It was important to go beyond merely passive protection, carried out piecemeal, and to have a comprehensive plan which would be prepared in advance and form a part of a development programme for the region as a whole.

Mr. D. J. Bellamy (Department of Botany, Durham) spoke next about moorlands, with special reference to the upland areas of Weardale and Teesdale in the west of the county. He outlined the quaternary history of these areas, and the importance of the peat cover as a wator-reservoir which controlled the run-off in the rivers. The maintenance and management of the upland areas gave rise to problems on which scientific research at Durham and elsewhere was in progress. Drainage, burning, grazing and afforestation of moorland all had ecological effects, both short- and long-term, which were complex.

Mr. B. A. Whitton (Department of Botany, Durham) then gavo a paper on reservoirs, rivers and pollution. He mentioned first the recent observations of the Hartlepools Water Co. on the stripping of hardness from the water flowing into Hurworth Burn Reservoir by a recently established 'meadow' of Chara. He then doseribed his own investigations of the alga Cladophora in the River 'Tees, and emphasized the need for such investigations in order to determine minimum river flows in summer. He suggested that the Hailsham Report was too compla. cent about the extent of pollution in the North-East. The role of the biologist in dealing with pollution problems had always been underestimated; and in view of the fact that pollution is becoming ever more complex and widespread, it was essential that problems should be tackled jointly by ehemists and biologists.
Mr. H. Porkins of Durham Sehocl took up the school. master's point of view, and discussed in particular the need for a new approach to the study of biology during the critical years, 11-16. What was needed here was a now syllabus, devised so as to be examinable, which would direct the pupils' attention to biology in its wider aspects of land use and conservation, and which put man into his place in Nature, both biologically and sociologically. Such a syllabus, devised by him, had recently been accepted by one of the examining boards. Its basis, after a year's introductory teaching on orthodox lines, was mapping, survey and collecting, done intensively and accurately in the field by the boys themselves. This was to be followed by an examination of a number of projocts in different fields, designed to introduce a variety of techniques; the techniques would not be an end in themselves, but would be related to the projects, as would the use of manuals for identification. Among other topies touched on by Mr. Perkins was the need for a new journal of field studies for schools, well produced and illustrated.

Mr. I. C. Laurie (Department of Town and Country Planning, University of Manchester) then talked about waste lands, with special reference to County Durham. He pointed out that, on a countrywide basis, dereliction of land showed a net increase, and that a continuous process of restoration was needed. In County Durham there wore areas of waste heaps from collieries, quarries and chemical factories, as woll as slum-cloarance sites and old railway areas, which were in need of attention. Over the past ten years a good deal had been done in the way of reclamation, particularly of pit-heaps. In some cases the heaps had been removed entirely and used for building purposes; in others, planting programmes had been devised and carried through. Treo-planting had been tried on twenty-nine sites, covering two hundred acres, and half a million trees had been planted: tho most successful trees were grey alder, birch and Corsican and lodgepole pine. Grass had also been sown in many places, often after the sites had beon levelled: here the most successful species were Deschampsia flexuosa, Agrostis tenuis and Dactylis glomerata. The results were variable, and research needed to be done on the natural succession in pit heaps, on a detailed investigation of the substratum, and on the autecology of the spocies suitable for planting; and here greater liaison was needed between the authorities concerned, such as the National Coal Board, and the local authorities and Univorsity scientists who were competent to do the research and give reasoned advice. Many dorelict areas could also, with reshaping and planting, bo transformed into attractive recreational areas.

Dr. M. E. Bradshaw (Extra-Mural Department, Durham) followed with a discussion on road-side verges, hedgerows and quarries. Sho omphasized the value to the biologist of the hedgerows and the verges, which, as relies of grassland and woodland, contained an immense variety of plant and animal species. Though these semi-natural habitats were extensively used all over the country as study-areas by groups of school children, few detailed ecological investigations of them had been made. They formed a buffer between the road and the agrieultural land beyond, which played its part in the protection of crops from damage and wind-erosion; and they also contributed greatly to the beauty and variety of the English countryside, a fact not without its importance for the tourist industry. Old quarries, too, were valuablo to the naturalist, as providing open habitats in which uncommon plants and animals could survive. Unrestricted quarrying and 
refuse tipping could destroy such habitats, with adverse effects on ecological research.

Another threat to wild-life was described by $\mathrm{Mr}$. N. H. Cleminson (Department of Zoology, Durham) in his talk on "Herbicides-Use or Abuse". He pointed out that herbicides were here to stay, and that although some of their long-term effects had yet to be discovered, many of the harmful effects so far reported were due to mistakes in application, which could be eliminated by education. The effocts of now herbicides such as paraquat, which killed all vegetation without apparently damaging the soil, were also described. These were likely to havo a profound effect on hill-farming, as they would allow the re-seeding of areas of moorland and bog hitherto inaccessible to orthodox farming techniques, and a consequent major increase in yield and stock-carrying capacity. Conservation policies in the moorlands of Britain, at least up to the 1,500-ft. line, would probably have to be re. shaped in the light of this revolutionary new technique.

The two remaining papers were given by Dr. J. L. Crosby and Mr. G. H. Banbury (both of the Department of Botany, Durham), and they dealt not with conservation but with recent technical advances in the plant sciences, with special reference to work going on at Durham. Dr. Crosby spoke on computers. Ho described applications of computer techniques to taxonomic and ecological problems, and then went on to describe his own work on genetic simulation and evolution. The computer provides an excellent way of constructing genetic models, and of demonstrating, for example, the action of natural selection in evolution. It also allows the exploration, on quite a new scalo, of the evolutionary changes in hybridizing populations under varying conditions of population size, hybrid sterility and so on.

Mr. Banbury spoke about the advances which had recently been made in molecular biology, and the ways in which new tochniques, such as electron microscopy and the use of radioactive tracers, were leading to exciting new developments in the plant sciences. Many of these at present were in the realm of pure research, but, as so often in the past, their application to practical problems, though not at present always foreseen, was bound to come.

The sessions were summed up by Mr. Grey. While recognizing the educational value of the conferonce, he emphasized the need to follow up the policies for conservation which had been outlined. For such policies to succeed, strong pressure from public opinion was needed-." a push from the bottom", and plans would have to be drawn up and put into effect. Here the University, the County Council and the Naturalists' Trust might all play a part. As an ex-miner, he particularly regretted that pit-heaps had ever come into being; this waste should have boon kept underground. $\mathrm{He}$ concluded by appealing for a planned study of County Durham which would cover not only Nature but also all other resources.

Some three hundred people, from schools, colleges, societies and local authorities, attended the conference; many of these also saw the demonstrations of work in progress which were on show in the Department of Botany.

D. H. VAlentine

\section{BOTRYTIS DISEASES OF PLANTS}

$I_{\mathrm{a}}^{\mathrm{N}}$ welcoming the forty participants at a conference, arranged by the East Malling Research Station with the support of the Agricultural Research Council during February 27-28, the director, Dr. F. R. Tubbs, spoke of the extensive losses caused by the polyphagous plant parasitic fungus Botrytis cinerea, in particular on soft fruits, tomatoes and lettuce. Dr. Tubbs thanked the Council for facilitating the attendance of specialist workers from Belgium, West Germany and Sweden.

The proceedings on the first day, under the chairmanship of Dr. Rudd Jones (Agricultural Research Council), dealt with the incidence of Botrytis infections and their relation to environmental factors. The second day, with Dr. A. F. Posnette (East Malling) as chairman, was devoted to the principles and practice of control measures.

Dr. R. K. S. Wood (Imperial College of Science and Technology, London) described work being done at the College by R. P. Purkayastha and Dr. B. J. Deverall on the infection of broad bean plants by the virulent species Botrytis fabae and the much less aggressive species $B$. cinerea. The differences in the behaviour of these two parasites seem to be explained by the fact that, although the lesions caused by $B$. cinerea are much smaller than are those caused by $B$. fabae, they contain greater amounts of substances which retard the growth of both parasites. Whether or not these substances are phytoalexin in nature remains to be determined. Dr. A. R. Wilson (Scottish Horticultural Research Institute, Mylnefield) showed that Botrytis infections of tomato stems after de-leafing entered through the vessels of the cut petiole, especially in older plants and at upper nodes. Latent infections resulted from the intake of dry spores into vessels where they remained temporarily ungerminated.

The three following papers were concerned with Botrytis attacks on raspberry and strawberry. Dr. W. R. Jarvis (also from Mylnefield) stressed the importance of flower infection. Rainfall and high humidity during blossoming were correlated with Botrytis rotting of strawberry fruits. In raspberry the weather during picking was the most important factor: long intervals between picks enhanced infection. D. W. Way (East Malling), reporting joint work with Dr. W. S. Rogers, related the habit of strawberry varioties to their infectibility. In the resistant Redgauntlet the fruit was well exposed: in the susceptible Merton Princess the loaves formed a close canopy concealing the berries. Wide spacing of the plants reduced rots but also diminished yield per acre; irrigation increased yield more than it increased wastage; nitrogen had little effect. Raspberry breeding work for the avoidance of Botrytis attack on the canes was discussed by Dr. R. L. Knight (East Malling). Only 4 per cont of hairy canes showed this disease compared with 34 per cent of glabrous canes: hairiness is controlled by a single dominant gene and hairy segregates in crosses wore resistant. However, another source of resistance had been found in one glabrous variety $(86 / 70)$ and this resistance was transmitted in crosses. Other lines of work being pursued aimed at the production of raspberry varieties with firm, well-spaced and exposed fruit.

Dr. R. G. Tomkins (Ditton Laboratory), dealing with tomato storage, noted that storage at $35^{\circ} \mathrm{F}$ retards rotting but increases skin susceptibility. Thus, when these tomatoes are transferred to a temperature of $50^{\circ} \mathrm{F}$, rots arise over their whole surface. When, however, tomatoes are kept at $50^{\circ} \mathrm{F}$ throughout, rotting arises at the calyx end only. Attack can be checked by the use of paper wraps impregnated with the acetate of o-phenyl phenol.

The discussion ranged chiefly around the factors affecting strawberry resistance and the frequency of Botrytis spores on and around the plants. Dr. Posnette stressed the seasonal variations in apparent resistance or susceptibility arising from weather and duration of gathering, whilo Ir. G. L. Gilles (Gorsem, Belgium) recorded that strawborries could not be infected by Botrytis spores unless they remained wet for $12 \mathrm{~h}$. Dr. M. H. Moore (East Malling) reported that moistened over-wintered strawberry leafstalks produced great numbers of spores: Dr. Jarvis stated that peak spore loads occurred in the 